УДК [378.147:373.3.011.3-051]:004

DOI:

Вікторія Гринько, кандидат психологічних наук, дочент кафедри природничоматематичних дисииплін та інформатики в початковій освіті, ДВНЗ “Донбаський державний педагогічний університет”

\title{
ВИКОРИСТАННЯ ЦИФРОВИХ ТЕХНОЛОГІЙ ДЛЯ ФОРМУВАННЯ У МАЙБУТНІХ УЧИТЕЛІВ УМІНЬ ХХІ СТОЛІТТЯ
}

У статті актуалізовано проблему підготовки майбутніх учителів початкової школи до успішного здійснення професійної діяльності в умовах інформаџійного соиіуму, щзо вимагає оволодіння уміннями прачювати з великими обсягами інформачійних повідомлень, критично мислити, бути комунікабельними, ініціативними, відповідальними, креативними. Детально проаналізовано ключові уміння ХХІ століття, визначення їх ролі в підготовиі майбутніх учителів та виокремлення умов, за яких можливе успішне їх формування, а також охарактеризовано можливості иифрових технологій як ефективного засобу навчання студентів закладів вищої освіти. Представлено рамкові документи Європейської комісії та законодавчі документи Украйни, які визначають головні орієнтири професійної підготовки майбутніх учителів, серед яких визначальним є широке запровадження цифрових технологій. Охарактеризовано підходи зарубіжних $і$ вітчизняних науковиів до використання иифрових технологій у формуванні ключових умінь студентів.

Ключові слова: ключові уміння ХХІ століття; иифрові освітні технологї̈; ијифрові освітні ресурси; майбутні учителі початкової школи; успішна професійна діяльність.

Jim. 15.

Viktoriya Hrynko, Ph.D.(Psychology), Associate Professor of the Natural Sciences, Mathematics, and Computer Studies in Primary Education Department, SHEI "Donbas State Pedagogical University"

\section{THE USE OF DIGITAL TECHNOLOGIES FOR DEVELOPING THE FUTURE TEACHERS' 21ST CENTURY SKILLS}

In the article the issue of future primary school teachers is considered as relevant for the successful performance of their professional activities in the conditions of the information society that require mastering the skills to work with a great amount of information sources, to think critically, to be sociable, initiative, responsible, and creative. The detailed analysis of the 21st century skills is presented, as well as their role in training of teacher is defined. The conditions, under which the development of the 21st century skills is possible, are described. The opportunities of digital technologies as an effective means of teaching students of higher educational institutions are characterized. The author refers to the frame documents of European Commission and the educational regulatory documents of Ukraine that define the main guidelines of the future teachers' professional training. The wide implementation of digital technologies is the most essential among them.

It is proved in the research that the use of digital technologies and digital resources contributes to the development of the 21st century skills. It is emphasized that it is difficult to distinguish all the educational opportunities of digital technologies as the rapid technological progress causes innovative means whose educational potential is constantly increasing.

It is concluded that it is important to train future teachers to improve continuously their technological skills and develop the ability to make the reasonable choice of the learning means for enhancing the quality of professional performance, especially in terms of preparing students for successful life in the information society.

Keywords: key 21st century skills; digital educational technology; digital educational resources; future primary school teachers; successful professional performance.

$\Pi$ остановка проблеми. Головним завданням сучасної системи освіти $\epsilon$ навчити людину вчитися. Формування вміння вчитися тісно пов'язано з розвитком здатності орієнтуватися в інформаційних потоках, ефективно комунікувати під час здійснення навчальної діяльності, виявляти свій творчий потенціал, знаходити шляхи самовираження та самореалізації в професійній та особистісній життєвих сферах. Усі перелічені ознаки є ключовими вміннями XXI століття, які $є$ необхідними для виховання успішної особистості. Швидкі темпи розвитку інформаційнокомунікаційних технологій і запровадження сучасних педагогічних інновацій в освітній процес закладів вищої освіти дозволяють розглядати цифрові технології як засіб формування ключових умінь XXI століття. 


\section{ВИКОРИСТАННЯ ЦИФРОВИХ ТЕХНОЛОГІЙ ДЛЯ ФОРМУВАННЯ У МАЙБУТНІХ УЧИТЕЛІВ УМІНЬХХІСТОЛІТТЯ}

Аналіз основних досліджень і публікацій. Різні аспекти формування ключових умінь XXI століття та використання цифрових технологій $\epsilon$ предметом дослідження цілої низки вітчизняних та зарубіжних науковців.

Серед українських учених значний внесок у інформатизацію освіти зробили В. Андрущенко, В. Биков, І. Вакуленко, Л. Гаврілова, М. Жалдак, М. Лещенко, А. Коломієць, Л. Наконечна (визначення основних термінів у сфері інформатизації освіти), О. Падалка (створення інформаційного освітнього середовища), С. Полат, T. Тарнавська (запровадження засобів IКТ в освітній процес закладів вищої освіти) та інші. Вивченню впливу цифрових технологій на оптимізацію освітнього процесу вищої школи присвячено дослідження О. Семеног, П. Стефаненка, В. Стрельнікова, Т. Тарнавської, Л. Тимчук та інших.

Українська вчена Н. Балик наголошує, що соціальні та інформаційні компетентності $\epsilon$ необхідними студентам педагогічних університетів для успішної адаптації в сучасному світі, а також дослідниця розробляє методологію їх формування. Н. Морзе досліджує шляхи формування колаборативних умінь студентів, визначає критерії оцінювання цих умінь. Л. Варченко-Троценко розробила методику електронної співпраці студентів із метою формування колаборативних та комунікативних умінь [4]. Л.Тимчук, проаналізувавши рамку компетентностей і умінь XXI століття [7], що поєднує критичне мислення, колаборацію, комунікацію, креативність, а також інформаційні, медіа, технологічні, життєві та кар'єрні вміння пропонує формувати у майбутніх магістрів освіти ці уміння на основі використання цифрових наративів.

П. Лещенко звернувся до вивчення зарубіжного досвіду реалізації навчання, яке характеризує навчальний процес, в якому центральнуроль відіграють цифрові (комп'ютерні) ігри. Автор наголошує, що цифрові ігри використовуються як засіб формування вмінь XXI століття в американських учнів у формальній та неформальній освіті [3].

Вивчення зарубіжного досвіду запровадження цифрових технологій в освітній процес дозволило виявити, що до проблеми формування умінь XXI століття зверталися В. Allen, H. Caple, D. Charalambidis, K. Coleman, T. Issa, C. Lewin, S. McNicol, T. Nguyen, J. Voogt та інші. Так британські дослідники C. Lewin та S. McNicol вважають, що інформаційно-комунікаційні технології $€$ визначальними у формуванні вмінь
XXI століття [14]. J. Voogt наголошує, що формування цих ключових умінь може відбуватися поза межами формальної освіти [15]. Зарубіжні дослідники також вивчають питання збільшення інтересу до використання соціальних мереж для створення ефективного навчального середовища як засобу формування вмінь XXI століття. В. Allen, H. Caple, K. Coleman i T. Nguyen присвятили свої праці проблемі професійного становлення студентів вищих навчальних закладів шляхом їхнього залучення до активного обговорення навчального контенту в соціальних спільнотах, а також ведення студентами власних мікроблогів [9].

D. Charalambidis докладно аналізує уміння XXI століття, пропонуючи способи застосування креативного підходу до використання засобів інформаційно-комунікаційних технологій для формування особистої та соціальної відповідальності, креативного способу мислення та цифрової компетентності. Дослідник також розглядає питання необхідності вчителів формувати ці вміння в учнів.

Отже, аналіз науково-педагогічної літератури доводить, що нині $є$ певні напрацювання щодо шляхів формування ключових умінь XXI століття серед студентів закладів вищої освіти. Однак, вивчення та висвітлення питань застосування цифрових технологій задля формування цих умінь, а також умови їх формування $є$ недостатніми.

Метою статті $€$ детальний аналіз ключових умінь XXI століття та можливостей сучасних цифрових технологій як ефективного засобу навчання майбутніх учителів початкової школи.

Виклад основного матеріалу дослідження. Широко відомим загалу є той факт, що роль цифрових технологій упродовж останніх років значно зросла, що вимагає перегляду змісту ключових умінь не з наукової точки, а з позиції їх щоденного застосування. Ключові вміння XXI століття, за визначенням M. Binkley, $\epsilon$ комплексним поняттям, яке передбачає набуття вмінь, що сприяють успішній самореалізації особистості в навчанні, роботі та повсякденному житті [11]. На початку XXI століття більше двохсот провідних організацій світу, зокрема Apple, Cisco Systems, Inc., Intel and Microsoft Corporation, Oracle Education Foundation визначили рамку вмінь, які є ключовими для успішної особистості XXI століття.

До таких умінь належать: особиста та соціальна відповідальність, швидка адаптованість, комунікативні уміння, творчі уміння, креативне мислення, цифрова грамотність, уміння особистої взаємодії тощо. Беручи до уваги визначену рамку 


\section{ВИКОРИСТАННЯЦИФРОВИХ ТЕХНОЛОГІЙ ДЛЯ ФОРМУВАННЯ}

У МАЙБУТНІХ УЧИТЕЛІВ УМІНЬХХІ СТОЛІТТЯ

умінь, більшість вчених (C. Lewin, J. Voogt, П. Лещенко, Г. Скрипка) у своїх дослідженнях звертаються до розгляду колаборативних, комунікативних, креативних умінь та умінь критичного мислення як таких, що забезпечують успішність молодим людям у житті в майбутньому $[3 ; 5 ; 14 ; 15]$.

Слід також наголосити, що для того щоб учитель міг формувати уміння ХХІ століття, вони мають бути описані в державних освітніх документах, зокрема в Державному стандарті початкової загальної освіти і Державному стандарті базової і повної загальної середньої освіти. Аналіз стандартів засвідчив, що під час вивчення освітньої галузі "Мова і література" увага вчителя здебільшого сфокусована на формуванні комунікативних умінь та умінь співробітництва; освітня галузь “Суспільствознавство" націлена на формування вмінь розв'язання суспільних проблем, що корелюють із когнітивними вміннями та вміннями критичного мислення; завданням освітньої галузі “Математика" є розвиток критичного та творчого мислення учнів; освітня галузь "Природознавство" має на меті формувати здатність застосовувати набуті знання в практичній діяльності, під час пізнання світу, що належить до групи життєвих умінь ХХІ століття; наскрізною змістовою лінією освітньої галузі “Технології” є формування інформаційнокомунікаційних умінь особистості, що представлені в переліку умінь XXI століття як “інформаційні вміння і медіа грамотність”. Отже, відповідно до освітніх законодавчих документів учителі мають дбати про майбутнє своїх учнів і здійснювати успішне формування вмінь XXI століття.

Міністерство освіти і науки України, впроваджуючи концепцію “Нова українська школа", розробило особистісно-орієнтовану модель освіти, у рамках якої реалізуються принципи дитиноцентризму. У концепції наголошено, що освітній процес Нової української школи має бути організовано з урахуванням умінь XXI століття відповідно до індивідуальних та вікових особливостей, стилів навчальної діяльності, застосовуючи низку завдань - від комунікативних до творчих [1, 21]. Тому майбутніх учителів слід навчати, як підтримувати сильні риси та розкривати потенціал кожного учня.

У межах концепції Нової української школи ключовою компетентністю, яка має бути сформована як у учнів, так і вчителів, $\epsilon$ цифрова компетентність, яка передбачає відповідальну взаємодію 3 цифровими технологіями, які використовуються для здійснення навчальної, професійної діяльності та суспільної взаємодії.

Цифрові технології пронизують усі сфери людської діяльності. Відповідно до рамки цифрової компетентності вчителя, оновлений варіант якої було затверджено Європейською комісією в 2018 році, педагогічна діяльність учителя має бути спрямована на розширення професійного середовища, тобто вчитель має залучати цифрові технології для налагодження взаємодії з учнями, їхніми батьками, колегами та представниками різних інституцій для власного професійного розвитку [12]. Все це дозволяє нам стверджувати, що майбутні вчителі мають застосовувати цифрові технології у своїй професійній діяльності та глибоко усвідомлювати їх значення для успішної взаємодії з іншими особистостями [2].

Слід зазначити, що цифрова компетентність не зводиться лише до оволодіння навичками користування комп'ютерною технікою та засобами IКТ, вона передбачає формування когнітивних умінь, які представлено як здатність педагога до оволодіння знаннями про сутність і специфіку інноваційних технологій, їх види, ознаки, а також спроможність обирати оптимальні технології для вирішення завдань власної педагогічної діяльності. Аналізуючи когнітивний компонент цифрової компетентності, ми погоджуємося $з$ американським дослідником D. Belshaw, що головними характеристиками когнітивних умінь $€$ рівень поінформованості про функції цифрових засобів (спільне навігаційне меню, теги, хеш-теги), що дозволяє користуватися цифровими пристроями, платформами та інтерфейсами [10]. У освітньому процесі закладів вищої освіти широко застосовують сервіси електронного листування, пошукові системи, електронні бібліотеки, платформи дистанційного навчання, інструменти візуалізації навчального матеріалу тощо.

Необхідною умовою формування когнітивних умінь майбутніх учителів є залучення їх до дослідницької педагогічної діяльності. У зв’ язку 3 цим показниками сформованості когнітивних умінь вважаємо:

- методологічні знання, зокрема вміння сприймати дійсність із позицій системного підходу, сформованість загальнонаукових категорій;

- загальнотеоретичні знання та методичні вміння, знання принципів і методів педагогічного дослідження;

- уміння ефективно застосовувати інноваційні педагогічні технології (гностичні, проектувальні, конструктивні, організаційні, комунікативні).

Процес формування когнітивних умінь 


\section{ВИКОРИСТАННЯЩИФРОВИХ ТЕХНОЛОГІЙ ДЛЯ ФОРМУВАННЯ}

У МАЙБУТНІХУЧИТЕЛІВ УМІНЬХХІ СТОЛІТТЯ

майбутніх учителів реалізується через спостереження, споглядання, дослідження, коли майбутній учитель аналізує результати власної навчально-професійної діяльності. Отже, для цього процесу характерною є наявність рефлексивних механізмів самоспостереження, самовизначення та саморозвитку, тобто усвідомлення норм та моделей своєї професійної діяльності і відповідна оцінка своїх можливостей $[8,60]$. Активізація рефлексивної позиції тісно корелює з орієнтацією майбутнього вчителя на саморозвиток. Джерелом цього процесу $\epsilon$ система усвідомлених суперечностей у професійній діяльності. Тому умовою формування як когнітивних, так i рефлексивних умінь є створення ситуацій активізації позитивного самосприйняття.

До цифрових засобів, які допомагають формувати та вдосконалювати когнітивні уміння майбутніх учителів, належать ресурси для створення карт знань Bubbl.us, FreeMind, Coogle, інфографіки Infogr.am, Vizify тощо. Окрім зазначених сервісів, перевагу яким надають вітчизняні вчені (Скрипка та ін.), зарубіжні дослідники (J. Voogt, C. Crook) зазначають, що формуванню когнітивних умінь студентів сприяє ведення електронного портфоліо та власного блогу [15].

У XXI столітті бути успішним означає постійно розвивати уміння спілкування, взаємодії та співпраці 3 людьми. Комунікативні уміння посідають важливе місце серед умінь XXI століття, які передбачають формування здатності обмінюватися інформацією, критикувати та презентувати ідеї $[14,183]$. На думку Г. Скрипки, умовою формування комунікативних умінь студентів $€$ самостійне налагодження спілкування 3 метою вирішення навчальних та професійних завдань [5, $102-103]$. Цифрові технології $\epsilon$ засобом підтримки комунікації для реалізації освітніх та соціальних потреб особистості. До переліку цифрових інструментів, які набули широкого використання в закладах вищої освіти i які сприяють формуванню комунікативних умінь, належать GoogleDrive, Google Hangouts, Skype, a також електронні соціальні мережі, такі як Twitter, Facebook.

Зарубіжні науковці В. Allen, H. Caple, K. Coleman i T. Nguyen наголошують на ролі електронних соціальних мереж у формуванні комунікативних умінь студентів. У своєму досліджені вони докладно вивчили можливості електронної соціальної мережі Facebook, як одну 3 найпоширеніших соціальних спільнот для обговорення навчального матеріалу, аудіо- та відеозаписів, а також ведення мікроблогу [9].
C. Lewin i S. McNicol також довели ефективність електронної комунікації через електронну пошту, он-лайн конференції і простий обмін повідомленнями під час виконання навчальних завдань. Вони акцентують увагу на тому, що через запровадження цифрових технологій змінився стиль спілкування викладача зі студентом. Так, викладачі оцінюють і коментують дописи студентів в блогах та електронних соціальних мережах. Студенти використовують цифрові засоби для спілкування, встановлення нових контактів, розповсюдження власних ідей тощо [14]

Високий рівень сформованості комунікативних умінь $€$ необхідною умовою для формування міжособистісних взаємин, колаборації та роботи в команді. Колаборація в освітньому процесі, за визначенням R. Gentry, це взаємодія двох або більше осіб, які працюють разом на рівноправній основі задля вироблення рішень, які приводять до позитивних змін [13]. Тенденція до розширення традиційних меж навчальної аудиторії $\epsilon$ визначальною для формування умінь XXI століття. Очевидно, що студенти взаємодіють із своїми одногрупниками та викладачами поза стінами навчального закладу через використання цифрових технологій. Так, J. Voogt звернувся до проблеми формування умінь XXI століття через засоби неформальної освіти, ефективність яких він вбачає в раціональному їх використанні викладачами. Найбільш розповсюдженим засобом неформального спілкування між викладачем і студентами є електронні соціальні мережі, а саме Facebook i Twitter [15]. Дослідження засвідчили, що перевага саме цим соціальним мережам надається через легкість застосування, можливість бути успішним, а також задоволення, яке студенти отримують у результаті взаємодії в соціальній мережі. Результатом підвищеної зацікавленості науковців до електронних соціальних мереж $\epsilon$ розповсюджена взаємодія студентів в соціальних середовищах із метою вирішення навчальних завдань та організації подій.

На думку зарубіжних учених, умовами успішного формування колаборативних умінь $\epsilon$ впровадження завдань для студентів, спрямованих на активізацію корпоративної діяльності, і високий рівень мотивації щодо такого типу взаємодії.

Окрім електронних соціальних мереж увагу науковців привертають wiki-технології для створення корпоративних навчальних завдань, які чинять позитивний влив на формування умінь студентів обговорювати свої дописи $з$ іншими та вироблення адекватного ставлення до критики. 


\section{ВИКОРИСТАННЯЦИФРОВИХ ТЕХНОЛОГЙ ДЛЯ ФОРМУВАННЯ У МАЙБУТНІХ УЧИТЕЛІВ УМІНЬ ХХІСТОЛІТТЯ}

Українські вчені Н. Морзе і Л. Варченко-Троценко у своїх дослідженнях докладно проаналізували можливості застосування wiki-технологій для реалізації корпоративного навчання в закладах вищої освіти, визначивши наступні шляхи їх запровадження: написання рефератів, анотування статей та джерел із запропонованої теми, виконання дослідницьких робіт, обговорення проблемних питань в межах групи або спеціальності, захист проектів тощо. Запровадження wiki-технологій дозволяє створювати єдине навчальне середовище 3 урахуванням навчальних, професійних та особистісних потреб майбутніх учителів, активізувати їх до створення власних навчальних та методичних електронних ресурсів, реалізовувати активну взаємодію та співпрацю викладачів і студентів та студентів між собою через відкритий електронний простір [4].

Створення студентами власних блогів, wiki сторінок та сторінок у соціальних мережах надає їм свободу креативності в оформленні та публікації матеріалів, які стосуються їхньої навчальної діяльності. Креативність у контексті підготовки майбутнього вчителя формується на основі наслідування досвіду, ідеї, окремого прийому, методу із поступовим зменшенням питомої наслідувального і зростанням творчого компонента власної педагогічної діяльності.

Ознаками креативності вчителя є здатність створювати щось нове; нетрадиційний підхід до організації освітнього процесу; уміння знаходити творчі підходи до вирішення професійних завдань; готовність до імпровізації тощо.

У результаті теоретичних розвідок нами було 3'ясовано, що формування креативних умінь студента відбувається за умови залучення особистого життєвого досвіду та набуття професійного досвіду в процесі підготовки; наявності таких особистісних характеристик як творчі здібності, мотиви власної навчальнопрофесійної діяльності, творча уява; наявності вмінь оформлювати результати своєї діяльності засобами цифрових технологій тощо. Тому умовою формування креативних умінь майбутніх учителів є виконання творчих завдань, які вимагають від них гнучкості й критичності мислення, творчої уяви.

У дослідженнях зарубіжних учених (B. Allen, H. Caple, K. Coleman i T. Nguyen) особливого значення для формування креативних умінь студентів набуває користування електронними соціальними мережами [9]. Головною метою залучення студентів до соціальних мереж $\epsilon$ заохочення їх до створення та розповсюдження навчального контенту, представленого в цифровій формі. До цифрових технологій, які застосовують студенти для оформлення навчального контенту, належать Google Drive, пакети програмного забезпечення Microsoft Office, сервіси створення он-лайн презентацій Prezi й Emaze, фоторедактори, сервіси для створення колажів $\mathrm{i}$ альбомів, відеоредактори тощо.

Таким чином, ефективними умовами формування умінь XXI століття (когнітивних, комунікативних, колаборативних, креативних i технологічних) вважаються впровадження завдань для студентів, спрямованих на активізацію дослідницької корпоративної діяльності, на самостійне налагодження спілкування 3 метою вирішення навчальних та професійних завдань, залучення особистого життєвого досвіду на основі використання низки цифрових технологій.

Висновки. Сучасній молодій людині для успішного здійснення професійної діяльності потрібно вміти адаптуватися до умов праці, працювати 3 великими обсягами інформаційних повідомлень, критично мислити, бути комунікабельною, ініціативною, відповідальною, креативною. Необхідність формування цих умінь відображено в рамкових документах Свропейської комісії, ЮНЕСКО та законодавчих документах України, які визначають головні орієнтири професійної підготовки майбутніх учителів, серед яких визначальним є широке запровадження цифрових технологій.

У дослідження доведено, що використання цифрових технологій і цифрових ресурсів сприяе формуванню ключових умінь XXI століття.

Зазначимо, що в нашому дослідженні охарактеризовано не всі можливості цифрових технологій, які сприяють формуванню у майбутнього вчителя умінь ХХІ століття,оскільки стрімкий технологічний прогрес невпинно породжує інноваційні засоби, освітній потенціал яких постійно зростає.

Важливим $є$ навчити майбутніх учителів постійно удосконалювати технологічні уміння i розвивати здатність здійснювати аргументований вибір того чи іншого навчального засобу для підвищення якості професійної діяльності, особливо в аспекті підготовки студентів до успішного життя в інформаційному суспільстві.

Перспективними напрямами подальших розвідок можна вважати вивчення питання формування умінь XXI століття через запровадження технологій мобільного навчання в освітній процес підготовки майбутніх учителів. 


\section{ВИКОРИСТАННЯЦИФРОВИХ ТЕХНОЛОГІЙ ДЛЯ ФОРМУВАННЯ У МАЙБУТНІХ УЧИТЕЛІВ УМІНЬ ХХІ СТОЛІТТЯ}

ЛІТЕРАТУРА
1. Концепція “Нова українська школа”: прийнята 27
жовтня 2016. URL: $\mathrm{http://mon.gov.ua/activity/education//}$
$\frac{\text { zagalna-serednya/ua-sch-2016/konczepcziya.html }}{2 . \text { Кучаковська Г. Інструменти соціальних сервісів у }}$
процесі колаборативного навчання майбутніх вчителів
початкової школи. Освітологічний дискурс. 2018. № 3-
4(22-23). С. 234-245
3. Лещенко П. Організаційно-педагогічні умови
застосування комп'терних ігор у навчальному процесі
середніх навчальних закладів освіти США. Автореферат
на здобугтя наук.ст.канд.пед.наук 13.00.01.Полтава, 2019.
22 с.

4. Морзе Н., Варченко-Троценко Л. Формування навичок ефективної співпраці студентів під час використання Вікі-порталу. Інформаційні технології $i$ засоби навчання. 2014. №2(40). C. 92-106. DOI: https:// doi.org/10.33407/itlt.v40i2.1015

5. Скрипка Г. Формування в учнів навичок XXI століття засобами інформаційно-комунікаційних технологій. Інформаційні технології і засоби навчання. 2016. №4(54). C. 99-107. DOI: https://doi.org/10.33407/ itlt.v54i4.1410

6. Тарнавська Т. Цифрові технології у навчальній, дослідницькій та інноваційній діяльності закладів вищої освіти. Психолого-педагогічні науки. 2016. №2. С. 110117.

7. Тимчук Л. Теоретико-методичні засади проектування цифрових наративів унавчанні майбугніх магістрів освіти: автореферат дисертації на здобуття наукового ступеня доктора педагогічних наук зі спеціальності 13.00.10 - інформаційно-комунікаційні технології в освіті. Київ, 2017. 24 с.

8. Умінська А. Формування рефлексивної культури майбутнього вчителя іноземної мови у процесі професійної підготовки: дис. на здобуття наук. ступеня канд.пед. наук: 13.00.04. Житомир, 2017. 199 с.

9. Allen, B., Caple, H., Coleman, K., \& Nguyen, T. (2012). Creativity in practice: social media in higher education. Proceedings of ASCILITE-Australian Society for Computers in Learning in Tertiary Education Annual Conference 2012. Willington: Australasian Society for Computers in Learning in Tertiary Education, 2012. pp. 15-20.

10. Belshaw, D. What is "digital literacy"?: $\mathrm{PhD}$ dissertation. Durham University, 2011. 274 p.

11. Binkley, M., Erstad, O., Herman, J., Raizen, S., Ripley, M., Miller-Ricci, M., Rumble, M. (2012). Defining Twenty First Learning Skills. Assessment and Teaching of 21st Century Skills. Dordrecht: Springer, 2012. pp. 17-66.

12. Framework for 21 st century learning. Available at: http://www.p21.org/ourwork/p21-framework

13. Gentry, R. Collaboration skills pre-service teachers acquire in a responsive preparation program. Journal of Instructional Pedagogies. 2012. No.8. Available at: https:/ /www.aabri.com/manuscripts/121106.pdf

14. Lewin, C., McNicol, S. Supporting the Development of 21st Century Skills through ICT. KEYCIT 2014: Key competencies in informatics and ICT. 2015. pp. 98-181.

15. Voogt, J., Erstad, O., Dede, C., \& Mishra, P. (2013). Challenges to learning and schooling in the digital networked world of the 21 st century. Journal of Computer Assisted Learning. 2013. No.29. pp. 403-413.

\section{REFERENCES}

1. Kontseptsiia "Nova Ukrainska shkola" [Concept "New Ukrainian school"]. (2016, October 27). Available at: http://mon.gov.ua/activity/education/zagalna-serednya/ ua-sch-2016/konczepcziya.html [in Ukrainian].

2. Kuchakovska, H. (2018). Instrumrnty sotsialnykh servisiv u protsesi kolaboratyvnoho navchannia maibutnikh vchyteliv pochatkovoi shkoly [Tools of social services in the process of future primary school teachers' collaborative training]. Educational Discourse, no. 3-4 (22-23), pp.234-245 [in Ukrainian].

3. Leshchenko, P. (2019). Organizatsiino-pedahohichni umovy zastosuvannia kompiuternykh ihor u navchalnomu protsesi serednikh navchalnykh zakladiv osvity SSHA [Organisational and pedagogical conditions of using computer games in educational process of secondary schools in the USA]. Extended abstract of Candidate's thesis. Poltava: Poltava V. G. Korolenko National Pedagogical University [in Ukrainian].

4. Morze, N \& Varchenko-Trotsenko, L. (2014). Formuvannia navychok efektyvnoi spivpratsi studentiv pid chas vykorystannia wiki-portalu [Developing the skills of effective cooperation of students while using Wikiportal]. Information technologies and learning tools, no.2(40), pp.92-106. DOI: https://doi.org/10.33407/ itlt.v40i2.1015 [in Ukrainian].

5. Skrypka, H. (2016). Formuvannia v uchniv navychok XXI stolittia zasobamy informatsiino-komunikatsiinykh tekhnolohii [Developing students XXI century skills by means of ICT]. Information technologies and learning tools, no.4(54), pp.99-107. DOI: https://doi.org/10.33407/ itlt.v54i4.1410 [in Ukrainian].

6. Tarnavska, T. (2016). Tsyfrovi tekhnolohii u navchalnii, doslidnytskii ta innovatsiinii diialnosti zakladiv vyshchoi osvity [Digital technologies in learning, research and innovative activities of higher educational institutions]. Psychological and Pedagogical Sciences, no.2, pp.110-117 [in Ukrainian].

7. Tymchuk, L. (2017). Teoretyko-metodychni zasady proektuvannia tsyfrovykh naratyviv u navchanni maibutnikh mahistriv osvity [Theoretical and methodological foundations of projecting the digital narratives in the training of future Masters of education]. Extended abstract of Doctor's thesis. Kyiv: Institute of Information Technologies and Learning Tools of NAPS in Ukraine. [in Ukrainian].

8. Uminska, A. (2017). Formuvannia refleksyvnoi kultury maibutnoho vchytelia inozemnoi movy u protsesi profesiinoi pidhotovky [Developing future foreign language teacher's reflective culture]. Candidate's thesis. Zhytomyr. [in Ukrainian].

9. Allen, B., Caple, H., Coleman, K., \& Nguyen, T. (2012). Creativity in practice: social media in higher education. Proceedings of ASCILITE - Australian Society for Computers in Learning in Tertiary Education Annual Conference 2012. (pp. 15-20). Willington: Australasian Society for Computers in Learning in Tertiary Education [in English]. 
10. Belshaw, D. (2011). What is "digital literacy"? $P h D$ dissertation. Durham University [in English].

11. Binkley, M., Erstad, O., Herman, J., Raizen, S., Ripley, M., Miller-Ricci, M., Rumble, M. (2012). Defining Twenty First Learning Skills. In Griffin, P., Mc Gaw, B., Care, E. (Eds.) Assessment and Teaching of 21st Century Skills (pp. 17-66). Dordrecht: Springer. [in English].

12. Framework for 21 st century learning. Available at: http://www.p21.org/ourwork/p21-framework [in English].

13. Gentry, R. (2012). Collaboration skills pre-service teachers acquire in a responsive preparation program.
Journal of Instructional Pedagogies, no.8. Available at: https://www.aabri.com/manuscripts/121106.pdf[in English].

14. Lewin, C. \& McNicol, S. (2015). Supporting the Development of 21 st Century Skills through ICT. In T. Brinda, N. Reynolds, R. Romeike, \& A. Schwill (Eds.). KEYCIT 2014: Key competencies in informatics and ICT (pp. 98-181). [in English].

15. Voogt, J., Erstad, O., Dede, C., \& Mishra, P. (2013). Challenges to learning and schooling in the digital networked world of the 21 st century. Journal of Computer Assisted Learning, no.29, pp.403-413. [in English].

Стаття надійшла до редакції 20.03.2019

УДК 378.4(73):63

DOI:

Наталія Гаврилюк, кандидат педагогічних наук, доцент кафедри украӥнської та іноземних мов Вінницького національного аграрного університету

\section{ПРОФЕСІЙНА КОМПЕТЕНТНІСТЬ ТА САМОРЕАЛІЗАЦІЯ СТУДЕНТІВ ЯК ПЕДАГОГІЧНА ПРОБЛЕМА}

Окреслено важливість проблеми становлення вищої аграрної освіти в Україні. Здійснено аналіз літературних джерел, в яких розкривається сутність понять “професіоналізаиія”, “професійна ідентифікаиія”, “професійний розвиток”, “професійне становлення”, “"рофесійна компетентність”, "професійна ідентичність", "професійне самовизначення”, “"роофесійне навчання”. Виявлено, ще професійна компетентність тлумачитися по-різному, хоча наявні певні схожості. Здійснено огляд ключових компонентів поняття "професійна компетентність".

Ключові слова: професіоналізація; професійне становлення; професійна компетентність; професійне самовизначення; професійне навчання, аграрна освіта.

Jim. 15.

Nataliya Havrylyuk, Ph.D.(Pedagogy), Associate Professor of the Ukrainian and Foreign Languages Department, Vinnytsya National Agrarian University

\section{PROFESSIONALSELF-REALIZATIONAND COMPETENCE OF STUDENTS AS A PEDAGOGICAL PROBLEM}

The importance of the problem of the formation of higher agricultural education in Ukraine is highlighted. The analysis of literary sources reveals the essence of the concepts of professionalization, professional identification, professional development, professional competence, professional identity, professional self-determination, and professional training, which determines the choice and occupation of the profession throughout life, which is considered as the basis of our study on the definition of the paths leading to the professional self-realization of future specialists in the agrarian sector.

The theoretical study has proven that under professionalization we will consider the process of formation of professional self-realization of future specialists of agrarian sector, which includes the choice of agrarian profession, taking into account its own capabilities and needs; assimilation of the rules and norms of the profession of agrarian; self-awareness as an agrarian; self-development by means of the profession; the process of entering a future specialist into a profession.

Professional competence is interpreted: 1) as a personality trait, namely, the totality of knowledge, skills, abilities, values and beliefs that are used to set goals in their future professional activity of the guidance and personality characteristics of a specialist, on the basis of which he defines the goals of professional activity; 2) as signs of a division. It means the activity of a specialist who uses his knowledge, skills and abilities and is able to think critically; 3) as an experience. It is stated that the personal experience of professional activity of a person is based on the acquired knowledge, values and skills that were obtained during the study; 4) as a tumor, which is the result of the received education, which promotes thesocialization of the individual and the creation of professional knowledge; 5) as a combination of competencies, general-purpose and narrow-professional.

It has been found that professional competence is interpreted differently, although there are certain similarities. A review of the key components of the concept "professional competence" was conducted.

Keywords: professionalization; professional formation; professional competence; professional selfdetermination; vocational training; agrarian education.

П

остановка проблеми. На сучасному етапі розвиток вищої аграрної освіти є надто актуальною темою, адже вона

знаходиться під сильним впливом перетворень у сучасному суспільстві. Під час освітніх змін головним завданням у системі вищої аграрної 